\title{
Keanekaragaman Perifiton pada Daun Lamun Enhalus acoroides dan Cymodocea serrulata di Pulau Parang, Karimunjawa
}

\author{
Raden Ario*, Ita Riniatsih, Ibnu Pratikto, Pratiwi Megah Sundari \\ Departemen Ilmu Kelautan, Fakultas Perikanan dan Ilmu Kelautan, Universitas Diponegoro \\ Jl. Prof. Soedarto, SH Tembalang, Semarang, 50275 \\ Email: ario_1960@yahoo.com
}

\begin{abstract}
Abstrak
Keanekaragaman jenis lamun dan struktur morfologi yang cukup besar pada Enhalus acoroides dan Cymodocea serrulata memungkinkan ditumbuhi perifiton dimana dapat meningkatkan produktivitas primer. Penelitian bertujuan untuk mengetahui kelimpahan perifiton dan pola distribusinya serta hubungan kerapatan lamun terhadap kelimpahan perifiton di PulauParang, Karimunjawa. Penelitian yang dilaksanakan pada bulan Oktober 2018 menggunakan metode survei dan penentuan lokasi dipilih dengan menggunakan metode purposive sampling, sedangkan metode pengambilan data lamun melalui metode line transect quadrant yang mengacu pada metode seagrass watch. Pengambilan daun lamun untuk pengamatan perifiton menggunakan metode sapuan daun yang selanjutnya diamati dengan menggunakan metode sensus yaitu pengamatan total dengan alat sedgwick rafter counting chamber di bawah mikroskop. Nilai kelimpahan perifiton pada daun lamun Enhalus acoroides di Stasiun 1, Stasiun 2, dan Stasiun 3 berturut-turut sebesar $2654 \mathrm{sel} / \mathrm{cm}^{2}, 2831$ $\mathrm{sel} / \mathrm{cm}^{2}, 1435 \mathrm{sel} / \mathrm{cm}^{2}$. Sedangkan kelimpahan perifiton pada daun lamun Cymodocea serrulata di Stasiun 1, Stasiun 2, dan Stasiun 3 berurutan sebesar $0 \mathrm{sel} / \mathrm{cm}^{2}, 2376 \mathrm{sel} / \mathrm{cm}^{2}, 2890 \mathrm{sel} / \mathrm{cm}^{2}$. Kelimpahan tertinggi perifiton terdapat pada jenis lamun Enhalus acoroides, hal ini diduga karena Enhalus acoroides mempunyai penampang daun yang lebih lebar dan umur jaringan makrofil yang lebih lama. Perifiton yang mendominasi di Pulau Parang berasal dari Kelas Bacillariophyceae, diduga karena kelas ini memiliki kemampuan melekat pada substrat yang baik. Berdasarkan perhitungan Indeks Morisita maka diketahui bahwa sebaran perifiton di Pulau Parang adalah mengelompok. Kelimpahan perifiton dengan kerapatan lamun di Pulau Parang memiliki hubungan cukup erat.
\end{abstract}

Kata kunci : Perifiton, C. serrulata, E. acoroides, PulauParang.

\section{Abstract \\ Variety of Periphyton on Seagrass Leaves Enhalus acoroides and Cymodocea serrulata in Parang Island, Karimunjawa}

The variety of seagrass types and the morphological structure of Enhalus acoroides and Cymodocea serrulata allows periphyton to be grown. Periphyton can increase primary productivity and help the decomposition process of seagrass. This research aims to determine the periphyton abundance, periphyton distribution and seagrass density relationship towards periphyton abundance in Parang Island, Karimunjawa. This research was conducted on October 2018. The seagrass data was collected by using the line transect quadrant method refers to the seagrasswatch method. Taking seagrass leaf for periphyton observation using the leaf drainage method was then observed using the census method, which is a total observation with sedgwick rafter counting chamber. Periphyton abundance value on seagrass leaves of Enhalus acoroides at Station 1, Station 2, and Station 3 are $2654 \mathrm{cells} / \mathrm{cm}^{2}, 2831 \mathrm{cells} / \mathrm{cm}^{2}, 1435 \mathrm{cells} / \mathrm{cm}^{2}$ respectively. While periphyton abundance on the seagrass leaves of Cymodocea serrulata at Station 1, Station 2, and Station 3 are 0 cell/ $\mathrm{cm}^{2}, 2376 \mathrm{cells} / \mathrm{cm}^{2}, 2890 \mathrm{cells} / \mathrm{cm}^{2}$ respectively. The highest abundance of periphyton was observed on Enhalus acoroides leaves. This is presumably because Enhalus acoroides has a wider leaf section and longer age of macrophilic system. Periphyton that dominates in Parang Island comes from Class Bacillariophyceae. This is likely because this class has the ability to attach on a good substrate. Based on the calculation of the Morisita Index, it is known that the periphyton distribution in Parang Island is clustered. Periphyton abundance showed a strong relation with the seagrass density.

Keyword : Periphyton, C. serrulata, E. acoroides, Parang Island. 


\section{PENDAHULUAN}

Lamun termasuk tumbuhan berbunga (Angiospermae) yang hidup terendam dalam kolom air dan berkembang dengan baik di perairan laut dangkal. Ekosistem lamun merupakan salah satu ekosistem bahari yang paling produktif, sehingga dapat mendukung potensi sumberdaya yang tinggi pula (Ameilda dan Irma, 2016. Ditambahkan pula bahwa fungsi ekologis padang lamun adalah sebagai sumber utama produktivitas primer, menstabilkan dasar perairan dengan sistem perakarannya yang dapat menangkap sedimen (trapping sediment), tempat berlindung bagi biota laut, tempat perkembang biakan (spawning ground), pengasuhan (nursery ground), serta sumber makanan (feeding ground) bagi biota perairan laut, pelindung pantai dengan cara meredam arus, penghasil oksigen dan mereduksi $\mathrm{CO}_{2}$ di dasar perairan.

Keanekaragaman jenis lamun yang tinggi serta struktur morfologi daun dari beberapa jenis lamun yang berukuran cukup lebar memungkinkan untuk ditumbuhi perifiton (Ameilda dan Irma, 2016). Perifiton yang ditemukan pada permukaan daun lamun menjadikan produktivitas primer ekosistem lamun menjadi tinggi. Biomassa yang terbentuk merupakan sumber makanan alami bagi biota air yang lebih tinggi yaitu zooplankton, juvenil udang, moluska dan ikan (Nybakken, 1992).

Demikian pula yang dilakukan oleh Ameilda dan Irma, 2016 bahwa struktur komunitas perifiton pada makroalga Ulva lactuca di peraira Pantai Ulee Lheue Aceh akan memberikan produktivitas primer lamun menjadi tinggi.

Sehingga diperlukan penelitian mengenai organisme perifiton ini yang memiliki peranan penting dalam ekosistem perairan laut dangkal. Berbagai upaya harus dilakukan demi menjaga kelestarian perifiton yaitu dengan menjaga substratnya yang salah satunya adalah lamun, karena perkembangan perifiton juga tergantung pada kondisi substratnya.

Pulau Parang merupakan pulau yang berada di wilayah administratif Kecamatan Karimunjawa, Kabupaten Jepara, Jawa Tengah. Pulau Parang berada di sebelah barat Pulau Karimunjawa dan secara geografis terletak pada $05^{\circ} 44^{\prime} 36^{\prime \prime} \mathrm{LS}$ dan $110^{\circ} 14^{\prime} 34^{\prime \prime}$ BT. Pulau ini dihuni oleh penduduk yang sebagian besar bekerja sebagai nelayan tangkap.

\section{MATERI DAN METODE}

Materi penelitian yang digunakan adalah sampel perifiton dari daun lamun Enhalus acoroides dan Cymodocea serrulata yang ditemukan di Pulau Parang, Karimunjawa. Penelitian ini dilakukan pada Oktober 2018. Lokasi penelitian ditentukan dengan menggunakan metode Purposive random sampling. Unsur utama yang diperlukan dalam penelitian ini adalah keberadaan ekosistem lamun di perairan Pulau Parang, Karimunjawa. Selama penelitian juga diamati keberadaan jenis lamun yang ada, antara lain: Enhalus acoroides, Thalassia hemprichii, Syringodium isoetifolium, Cymodocea serrulata dan Haludule uninervis.

\section{Pengambilan Data Lamun}

Metode yang digunakan adalah metode Seagrass watch (Brower et al., 1990). Penelitian terbagi dalam 3 Stasiun yaitu Stasiun 1 (Batu Hitam), Stasiun 2 (Batu Merah), dan Stasiun 3 (Pelabuhan). Setiap Stasiun akan terbagi menjadi 3 substasiun. Jarak antar substasiun adalah 25 meter dan 50 meter ke arah laut.

Metode yang digunakan untuk pengambilan data lamun menggunakan transek kuadran $50 \mathrm{~cm}$ x $50 \mathrm{~cm}$. Masing-masing substasiun, garis transek ditarik garis sepanjang $50 \mathrm{~m}$ tegak lurus garis pantai dengan setiap $5 \mathrm{~m}$ ditetapkan masingmasing satu transek kuadran. Pengamatan dilakukan langsung di lapangan terhadap identifikasi spesies lamun, tegakan lamun, dan persentase penutupan lamun (McKenzie dan Campbell, 2003). Selanjutnya kondisi perairan yang diukur secara insitu meliputi suhu, DO, salinitas, $\mathrm{pH}$, salinitas, kecerahan, kedalaman dan substrat pada setiap stasiun.

\section{Pengambilan Sampel Lamun}

Pengambilan sampel lamun di lapangan dilakukan dengan menggunakan transek yang berukuran $50 \mathrm{~cm} \times 50 \mathrm{~cm}$. Transek diletakkan pada titik-titik sampling di Stasiun 1, 2, dan 3. Sebanyak 3 helai daun lamun di bagian pangkal sebagai sampel dari masing-masing jenis pada setiap substasiun pengamatan menggunakan gunting sepanjang $2 \times 5 \mathrm{~cm}$. Kemudian dilakukan perhitungan percent cover, jenis lamun, asosiasi makroalga dan asosiasi biota di hamparan padang lamun (Sarbini dan Yusup, 2015).

\section{Pengambilan Sampel Perifiton}

Pengambilan sampel perifiton dilakukan dengan metode sapuan dimana perifiton dipisahkan dari permukaan daun lamun dengan menggunakan kuas. Sampel daun lamun berukuran $2 \times 5 \mathrm{~cm}$ yang telah digunting selanjutnya diletakkan di atas cawan petri yang berisi aquades. Kemudian dilakukan sapuan 
menggunakan kuas. Sampel perifiton yang diletakkan dalam cawan petri dipindahkan ke botol $25 \mathrm{~mL}$. Selanjutnya ditambahkan aquades hingga volume mencapai $25 \mathrm{~mL}$ serta dilakukan pengawetan menggunakan formalin $4 \%$. Setiap sampel diberi label sesuai substasiun. Selanjutnya sampel perifiton diamati di bawah mikroskop (Sarbini dan Yusup, 2015).

\section{Analisa Data}

Kerapatan masing-masing jenis pada setiap stasiun dihitung berdasarkan rumus dari Brower et al., (1990). Indeks keanekaragaman jenis Shannon-Wiener menurut Brower et al., (1990). Indeks keseragaman jenis menurut Brower et al., (1990). Dominansi dinyatakan dalam indeks dominansi Simpson (Brower et al., 1990). Perhitungan kelimpahan jenis perifiton dilakukan dengan menggunakan rumus Harahap et al., (2015), yaitu:

$$
N=n \times \frac{V p}{V c g} \times \frac{1}{A}
$$

Keterangan : $\mathrm{N}=$ Kelimpahan perifiton $\left(\mathrm{sel} / \mathrm{cm}^{2}\right)$; $\mathrm{n}=$ Jumlah perifiton yang tercacah (sel); $\mathrm{Vp}=$ Volume pengencer $(25 \mathrm{~mL}) ; \mathrm{Vcg}=$ Volume sampel dibawah cover glass SRC $(1 \mathrm{~mL}) ; \mathrm{A}=$ Luas sapuan $\left(5 \times 2 \mathrm{~cm}^{2}\right)$

\section{Indeks Penyebaran Morisita}

Pola penyebaran perifiton pada daun lamun dapat diketahui dengan perhitungan menggunakan rumus Morisita (Odum, 1993). Kriteria Indeks Morisita: $\mathrm{Id}=1,0$ : Penyebaran acak; $\mathrm{Id}<1,0$ : Penyebaran merata; $\mathrm{Id}>1,0$ : Penyebaran mengelompok

\section{Keanekaragaman Perifiton}

Indeks keanekaragaman jenis dihitung dengan rumus Shannon-Wiener sebagai berikut (Ameilda dan Irma, 2016): $\quad H^{\prime}=-\sum(n i / N) \log (n i / N)$
Keterangan : H' = Indeks Keanekaragaman
Shannon; pi=ni/N = Jumlah spesies ke-I; ni = Jumlah individu jenis ke-I; $\mathrm{N}=$ Jumlah total individu

\section{HASIL DAN PEMBAHASAN}

Jenis lamun yang ditemukan di Pulau Parang didominasi spesies E. acoroides dan $C$. serrulata. Selain kedua spesies dominan tersebut juga terdapat spesies lamun $S$. isoetifolium, $H$. uninervis, dan T. hemprichii. Data lamun di Pulau
Parang selengkapnya terdapat pada Tabel 1 dan Gambar 1.

Stasiun 1 menunjukkan tingkat kerapatan lamun yang rendah dibanding stasiun lain dan hanya didominasi oleh satu spesies lamun yaitu $E$. acoroides. Stasiun 1 mempunyai kerapatan lamun sebesar $888 \mathrm{ind} / \mathrm{m}^{2}$. Hal ini diduga berkaitan dengan tipe substrat di lokasi ini. Stasiun I mempunyai tipe substrat berlumpur sehingga jenis lamun lain tidak bisa hidup pada tipe substrat berlumpur.

Stasiun 2 memiliki tingkat kerapatan yang tinggi dan merupakan lokasi yang paling banyak ditemukan jenis lamun sebanyak 4 jenis lamun yaitu E. acoroides, $C$. serrulata, T.hemprichii, dan H. uninervis. Stasiun 2 memiliki kerapatan lamun sebesar $956 \mathrm{ind} / \mathrm{m}^{2}$. Kondisi tersebut dikarenakan stasiun ini memiliki keadaan arus yang tenang yaitu sebesar $0,024-0,026 \mathrm{~m} / \mathrm{det}$. Widianingsih et al. (2009) menyatakan bahwa lamun umumnya dapat tumbuh baik pada perairan tenang.

Stasiun 3 memiliki tingkat kerapatan yang sedang. Lokasi ini ditemukan 3 jenis spesies lamun yaitu $E$. acoroides, $C$. serrulata dan $S$. isoetifolium. Didominasi oleh $C$. serrulata dikarenakan Stasiun 3 memiliki kisaran kedalaman $102-115 \mathrm{~cm}$ dan sudah tidak dipengaruhi pasang surut.

\section{Kelimpahan Perifiton}

Data kelimpahan yang diperoleh pada daun lamun Enhalus acoroides dan Cymodocea serrulata secara lengkap disajikan dalam Gambar 2 dan 3.

Perifiton yang ditemukan pada jenis lamun Enhalus acoroides di Pulau Parang terdiri dari 4 kelas dan 23 genus. Kelas Bacilariophyceae terdiri dari 18 genus yaitu Melosira, Pleurosigma, Coscinodiscus, Rhizosolenia, Diploneis, Hemiaulus, Fragilaria, Navicula, Biddulphia, Nitczhia, Striatella, Rhabdonema, Stephanodiscus, Grammatophora, Licmophora, Thalassiosira, Tropidoneis, Cylindrotheca. Kelas Dinophyceae ditemukan 2 genus yaitu Alexandrium dan Cochlodinium. Kelas Cyanophyceae hanya ditemukan satu genus yaitu Nodularia. Sedangkan untuk Zooplankton ditemukan Calanus dan larva bivalvia.

Komposisi perifiton pada daun Cymodocea serrulata ditemukan 4 kelas dan 25 genus. Kelas Bacillariophyceae terdiri dari 18 genus yaitu Melosira, Pleurosigma, Coscinodiscus, Rhizosolenia, Diploneis, Hemiaulus, Fragilaria, Navicula, Biddulphia, Striatella, Rhabdonema, Nictzhia, Stephanodiscus, Grammatophora, 
Thalassiosira, Cylindrtotheca, Skeletonema, dan Leptocylindrus. Kelas Dinophyceae terdiri dari 2 genus yang ditemukan yaitu Alexandrium dan Cochlodinium. Kelas Cyanophyceae terdiri dari 3 genus yaitu Oscilatoria, Nodularia dan Trichodesmium. Sedangkan Zooplankton terdiri dari Calanus dan larva bivalvia. Menurut Suwartimah et al. (2011), Kelas Bacillariophyceae memegang peranan penting di suatu perairan sehingga lebih mendominasi dalam segi jumlah dan jenisnya. Bacillariophyceae atau lebih dikenal dengan diatom merupakan perifiton jenis mikroalga yang paling banyak dijumpai bersel satu walaupun beberapa diantaranya ada yang berbentuk koloni. Frustule Bacillariophyceae berupa silika yang sukar dihancurkan, sehingga

Tabel 1. Kehadiran Jenis Lamun di Lokasi Penelitian

\begin{tabular}{ccccccc}
\hline \multirow{2}{*}{ Stasiun } & \multicolumn{7}{c}{$\begin{array}{c}\text { Enhalus } \\
\text { acoroides }\end{array}$} & $\begin{array}{c}\text { Cymodocea } \\
\text { serrulata }\end{array}$ & $\begin{array}{c}\text { Thalassia } \\
\text { hemprichii }\end{array}$ & $\begin{array}{c}\text { Halodule } \\
\text { uninervis }\end{array}$ & $\begin{array}{c}\text { Syringodium } \\
\text { isoetifolium }\end{array}$ \\
\hline \multirow{2}{*}{ Stasiun 1} & 1 & + & - & - & - & - \\
& 2 & + & - & - & - & - \\
& 3 & + & - & - & - & - \\
\hline Stasiun 2 & 1 & + & + & + & + & - \\
& 2 & + & + & + & + & - \\
\hline Stasiun 3 & 3 & + & + & - & - & + \\
& 2 & + & + & - & - & + \\
& 3 & + & + & & & + \\
\hline
\end{tabular}

Keterangan : + = Ditemukan, - = Tidak Ditemukan,

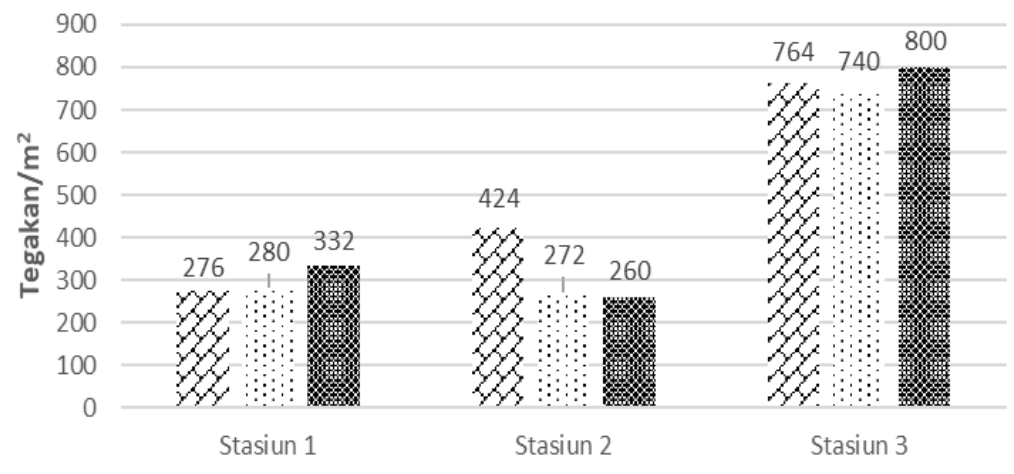

Keterangan Substasiun : $\quad<1: 2$

Gambar 1. Tingkat Kerapatan Lamun

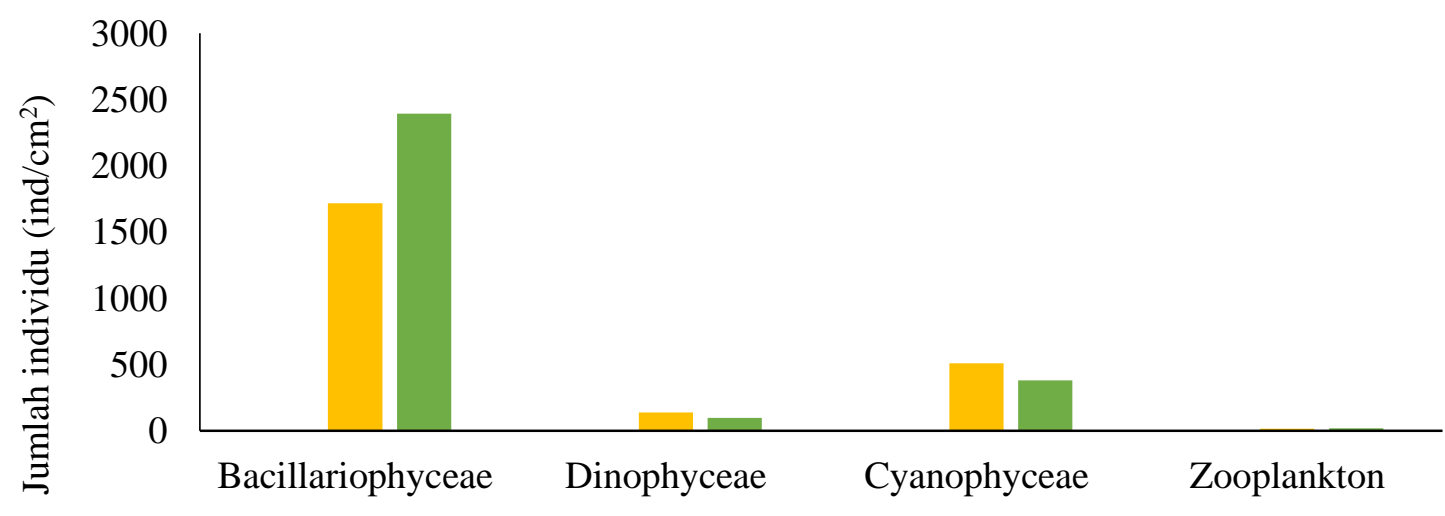

- Stasiun $1 \quad$ Stasiun $2 \quad$ Stasiun 3

Gambar 2. Kelimpahan perifiton pada daun Enhalus acoroides 


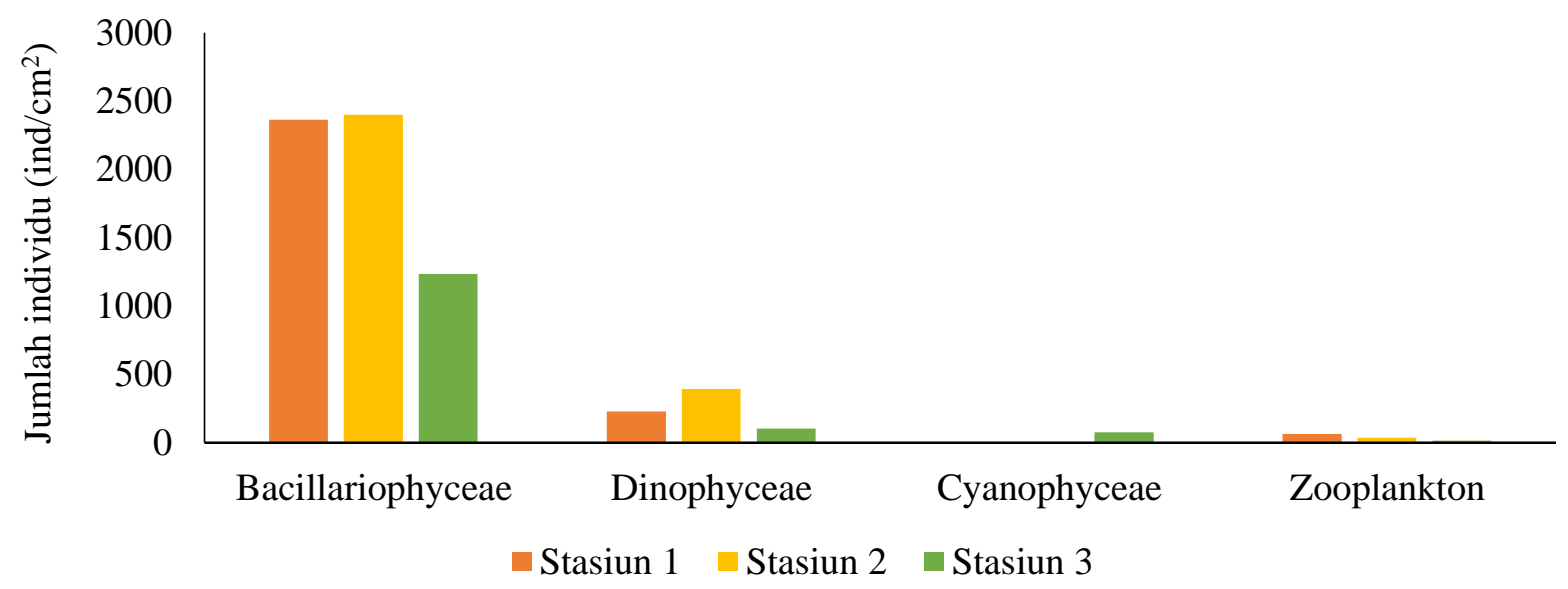

Gambar 3. Kelimpahan perifiton pada daun Cymodocea serrulata

perifiton kelas Bacillariophyceae dapat digunakan sebagai bioindikator untuk mengetahui tingkat pencemaran suatu perairan. Bacillariophyceae memiliki alat menempel pada substrat yang kuat karena diatom melalui raphe mengeluarkan mucopolysaccharide yang dapat menempel pada substrat (Widianingsih et al., 2009). Kemampuan melekat pada permukaan substrat yang lebih baik dibandingkan perifiton jenis lainnya menyebabkan keberadaan Bacillariophyceae lebih mendominasi suatu ekosistem.

Perifiton yang paling sedikit ditemukan di Pulau Parang adalah dari Kelas Dinophyceae. Jenis Dinophyceae yang ditemukan hanya terdiri dari 2 genus yaitu Alexandrium dan Cochlodinium. Dinophyceae atau Dinoflagellata memiliki 2 flagella yaitu: longitudinal dan transversal. Vibrasi oleh flagella longitudinal menggerakkan air ke belakang sedangkan flagella transversal akan menggerakan rotasi dan maju ke depan. Alexandrium merupakan organisme yang bersifat toksin karena menghasilkan PST (Paralytic Shellfish Toxin) dan dapat berasosiasi dengan lingkungan nitrogen yang tinggi (Widianingsih et al., 2009).

\section{Distribusi Perifiton}

Sebaran jenis perifiton pada daun lamun E.acoroides dan C.serrulata di Pulau Parang berdasarkan perhitungan Indeks Morisita diperoleh sebaran mengelompok. Seluruh genus yang didapatkan menunjukkan hasil Id yang > 1 sehingga mempunyai kesimpulan bahwa pola penyebaran perifiton pada daun lamun di lokasi penelitian adalah mengelompok atau berkoloni.

Pola sebaran yang berkoloni berkaitan erat dengan adanya nutrien di perairan yaitu konsentrasi fosfat dan nitrat. Hal ini seperti yang disebutkan Mandal et al., (2016) bahwa adanya pengaruh kandungan nutrient terhadap pola sebaran jenis organisme planktonik. Pola sebaran jenis biota disuatu perairan dipengaruhi oleh beberapa faktor, diantaranya seperti pola arus yang dapat menyebabkan terakumulasinya nutrient. Pola sebaran yang mengelompok berkaitan dengan organisme memilih daerah yang akan ditempati serta faktor kimia yang berpengaruh pada kehidupan organisme (Nybakken, 1992). Proses kolonialisasi merupakan pembentukan koloni perifiton pada substrat yang berlangsung segera setelah pengkoloni menempel pada substrat. Tipe substrat sangat menentukan proses kolonialisasi dan komposisi perifiton, hal ini berkaitan dengan kemampuan alat menempelnya. Kemampuan perifiton menempel pada substrat menentukan ketahanannya terhadap pencucian arus atau gelombang yang dapat memusnahkannya. Persebaran perifiton dipengaruhi oleh arah arus dan gelombang laut, dimana gelombang laut yang dihasilkan berasal dari angin dan musim. Faktor lain gelombang datang yaitu dari kapal-kapal nelayan yang melintas di wilayah Pulau Parang.

\section{Hubungan Kerapatan Lamun Dengan Kelimpahan Perifiton}

Berdasarkan nilai hubungan korelasi antara kerapatan lamun dengan kelimpahan perifiton pada daun lamun Enhalus acoroides di Pulau Parang didapatkan $\mathrm{r}$ sebesar 0,68 sedangkan pada lamun Cymodocea serrulata didapatkan nilai $r$ sebesar 0,65. Hal ini menunjukkan hubungan kerapatan lamun Enhalus acoroides dengan kelimpahan perifiton lebih kuat dibandingkan dengan Cymodocea serrulata.

Perifiton yang menempel pada substrat lamun dinamakan epifitik yang hidupnya menempel pada tumbuhan. Peran penting lamun 
di ekosistem perairan adalah mendukung produktivitas primer dan perifiton sebagai makanan alami biota lain seperti moluska, insekta, dan berbagai ikan yang hidup di padang lamun (Irawan dan Sari, 2011). Peran perifiton pada lamun membantu proses dekomposisi yaitu mempercepat proses pemutusan daun akibat padatnya penempelan perifiton sehingga daun yang jatuh akan didekomposisi oleh bakteri dan menghasilkan serasah dan endapan dasar yang akan dikonsumsi fauna dasar sedangkan partikel serasah yang tersuspensi dalam air merupakan makanan bagi filter feeder yang selanjutnya hewan-hewan tersebut akan menjadi mangsa hewan karnivora. Jika lamun sudah mati maka perifiton akan membantu pemutusan daun lamun sehingga lamun dapat bergenerasi dengan baik.

Organisme perifiton mempunyai peran dalam penyedia produktivitas perairan karena dapat melakukan proses fotosintesis yang dapat membentuk zat organik dari zat non organik dan memanfaatkan nutrient yang ada di ekosistem lamun (Novianti et al., 2013). Prakoso et al., (2015), menyebutkan bahwa epifitik yang hidup di lamun memanfaatkan lamun sebagai habitat dan juga memanfaatkan nutrien dari serasah lamun sebagai makanannya dengan demikian epifitik pada lamun memiliki hubungan atau asosisasi dengan lamun sebagai tempat berlindung, mencari makan, dan bertumbuh kembang. Perifiton yang berasosiasi dengan suatu ekosistem memiliki peranan yang sangat penting, yaitu sebagai salah satu mata rantai penghubung dalam aliran energi dan siklus materi dari alga planktonik sampai konsumen tingkat tinggi, seperti kepiting, ikan dan udang.

\section{KESIMPULAN}

Nilai kelimpahan perifiton pada daun lamun Enhalus acoroides di Stasiun 1, Stasiun 2, dan Stasiun 3 berturut - turut adalah : $2654 \mathrm{ind} / \mathrm{cm}^{2}$, $2831 \mathrm{ind} / \mathrm{cm}^{2}$, dan $1435 \mathrm{ind} / \mathrm{cm}^{2}$. Sedangkan kelimpahan perifiton pada daun lamun Cymodocea serrulata di Stasiun 1, Stasiun 2, dan Stasiun 3 berturut - turut adalah : 0 ind $/ \mathrm{cm}^{2}, 2376$ $\mathrm{ind} / \mathrm{cm}^{2}$, dan $2890 \mathrm{ind} / \mathrm{cm}^{2}$. Kelimpahan tertinggi perifiton terdapat pada jenis lamun Enhalus acoroides. Pola sebaran perifiton pada daun Enhalus acoroides dan Cymodocea serrulata di perairan Pulau Parang adalah mengelompok yang artinya komunitas perifiton hidup berkoloni. Hubungan dari kelimpahan perifiton dan kerapatan lamun di Pulau Parang mempunyai korelasi rendah.

\section{DAFTAR PUSTAKA}

Ameilda, C., \& Irma, D. 2016. Struktur Komunitas Perifiton pada Makroalga Ulva lactuca di Perairan Pantai Ulee Lheue Banda Aceh. Jurnal Ilmiah Mahasiswa Kelautan dan Perikanan Unsyiah. 1(3):337-347.

Brower, J. E., J. H. Zar \& C. Von Ende. 1990. General Ecology. Field and Laboratory Methods. Wm. C. Brown Company Publisher, Dubuque, Iowa.

Harahap, H.A., Adriman., \& Eni, S. 2015. Periphyton community structure in the seagrass ecosystem of the Malang Rapat Village Coast. Kepulauan Riau.

Irawan, A., \& Sari, L.I. 2011. Estimasi Potensi Luasan Daun Lamun Dalam Mendukung Produktivitas di Perairan Pesisir Kutai Timur. Jurnal Ilmu Perikanan Tropis, 19(2):219225.

Mandal. S., Hikaru, H., Anupam, P., Hans, B., Smith, S. L., Kaiw., Wirtz. \& Hidekatsu. Y. 2016. A 1D physical-biological model of the impact of highly intermittent phytoplankton distributions. Jurnal Plankton Research, 38 (4):964-976.

McKenzie, L.J. \& Campbell, S.J. 2003. Manual for Community Monitoring of Seagrass Habitat. Wester Pasific Edition. Seagrasswatch. Departemen of Primary Industries. Australia.

Nybakken, J.W. 1992. Biologi Laut, Suatu Pendekatan Ekologis. PT. Gramedia. Jakarta. $459 \mathrm{hlm}$.

Novianti, M ., Widyorini, N. \& Suprapto., 2013. Analisis Kelimpahan Perifiton Pada Kerapatan Lamun Yang Berbeda Di Perairan Pulau Panjang, Jepara. Journal of Managemen of Aquatiq Resources, 2(3):219225.

Odum, E.P., 1993. Dasar-dasar Ekologi. Edisi ketiga. Gadjah Mada University Press. UGM. Yogyakarta. $697 \mathrm{hlm}$.

Prakoso, K., Supriharyono \& Ruswahyuni. 2015. Kelimpahan epifauna di subtrat dasar dan daun lamun dengan karapatan yang berbeda di Pulau Pahawang Provinsi Lampung. Management Of Aquatic, 4(3): 177-122.

Sarbini, R. \& Yusup. N. 2015. Teknik Sampling dan Pengamatan Kelimpahan Perifiton di Ekosistem Lamun Kepulauan Karimun Jawa. Teknisi Litkayasa Balai Penelitian dan Pemulihan dan Konservasi Sumberdaya Ikan. BBAP Jepara.

Suwartimah, K., Widianingsih, W., Hartati, R. \& Wulandari, S.Y., 2012. Komposisi Jenis dan 
Kelimpahan Diatom Bentik di Muara Sungai Comal Baru Pemalang. Ilmu Kelautan: Indonesian Journal of Marine Sciences, 16(1):16-23.
Widianingsih., Retno, H., Hadi, E., dan Ria, A. 2009. Buku Ajar Mikroalga Laut. Badan Penerbit Universitas Diponegoro. Semarang. 